\title{
HOPELESS CASES: IN DEFENCE OF COMPENSATING LITIGANTS AT THE ADVOCATE'S EXPENSE
}

\author{
Duncan Webb *
}

The dividing line between novel litigation and cases which are an abuse of process and a waste of time can be a difficult one to draw. Some would argue that the tension between these two public policies is reason enough not to award costs against an advocate bringing or defending "hopeless" causes. The author, however, is of the view that the jurisdiction to award such costs is justified in the interests of protecting clients and maintaining professional standards. An analysis of the case law reveals that the power is used sparingly and, if there is any doubt, the court will favour the advocate.

\section{INTRODUCTION}

There are numerous reasons why a litigant may wish to bring a case or mount a defence which has no prospect of success. ${ }^{1}$ Few would disagree that the bringing of such cases should be discouraged. One way in which the courts have sought to discourage such cases is by compensating the successful litigant, and punishing the advocate ${ }^{2}$ for the unsuccessful side by awarding costs against the advocate for assisting in bringing the hopeless case or defence. Such awards are made on the ground that the court has an inherent jurisdiction to ensure that its procedure is not abused and used to achieve an injustice to one of the parties, and to punish misconduct of those who appear before it. ${ }^{3}$

* Senior Lecturer, Faculty of Law, Victoria University of Wellington. Thanks are due to the Centre for Legal Practice at the University of Exeter where this paper was completed while on research leave.

1 Motivations such as spite, a collateral advantage in related negotiations or litigation, or an unfounded belief that there is merit in the claim all come to mind.

2 This term will be used to denote any legal adviser who acts for a client in litigation, whether as a barrister or solicitor or both.

3 Assisting in the bringing of a hopeless case will in some cases be in breach of the Rules of Professional Conduct of Barristers and Solicitors. Rule 7.04 provides that: 
In most cases costs orders made by the courts will only partially compensate for the financial hardship of the trial, and can never compensate for the associated stress. How much greater then is the wrong done to the successful litigant when the opposing claim or defence is wholly without foundation. ${ }^{4}$ When a case is demonstrably hopeless the successful party has been put to the considerable cost and trouble of a trial for no cause whatsoever. This is one motivation for the longstanding attitude of the law in discouraging the bringing of hopeless cases. ${ }^{5}$

This paper seeks to the possible tensions that such a rule creates within the role of an advocate, and examine the basis on which the intervention of the court has been justified. By examining in greater detail the limited circumstances in which the courts have exercised the jurisdiction to order costs against an advocate it will be seen that the objections to the jurisdiction are not persuasive. Thus, my thesis is that a rule which compensates litigants who have been brought before the court to defend a hopeless cause (or dismiss a hopeless defence) by ordering the advocate to pay the costs (and thereby punishing the advocate) is justified.

\section{CONFLICTING POLICY CONSIDERATIONS}

The rule by which an advocate may be personally liable for loss suffered by their client's opponent has been objected to on a number of policy grounds. It is claimed that there is danger that an advocate's zeal may be cooled by the prospect of an adverse order of costs. Perhaps of more concern is the suggestion that deserving cases will go unlitigated, or possible defences not raised, because of the reluctance of advocates to press novel causes. In the leading English, Ridehalgh $v$ Horsefield, the clear tension between the competing policy interests was recognised when Sir Thomas Bingham MR noted that there is: 6

A practitioner must make all reasonable efforts to ensure that legal processes are used for their proper purposes only and that their use is not likely to cause unnecessary embarrassment, distress or inconvenience to another person's reputation, interests or occupation.

4 The issue addressed by this paper is the same whether the advocate is assisting with a hopeless case or hopeless defence. The principles applicable to the question of whether either will amount to an abuse of the process of the court are the same, see Chua $v$ ANZ (1997) 11 PRNZ 523 (HC). For the sake of clarity and brevity this paper has been written from the perspective of the prosecution of a hopeless case.

5 The problem is an ancient one: Laws 1, 3 \& 4 of Hammurabi provided that where unsubstantiated claims were brought the wrongful claimant was liable for the defendant for the sanction claimed (even death), see Law Collections from Mesopotamia and Asia Minor (2 ed, Society of Biblical Literature, Atlanta, 1997). Justinian's Institutes provide at Book IV Title XVI that an advocate must swear an oath as the belief of the veracity of the claim or defence.

6 [1994] Ch 205, 206 (CA). 
a tension between two important public interests. One is that lawyers should not be deterred from pursuing their clients' interests by fear of incurring personal liability to their clients' opponents; that they should not be penalised by orders to pay costs without a fair opportunity to defend themselves; that wasted costs orders should not become a back-door means of recovering costs not otherwise recoverable against a legally aided or impoverished litigant; and that the remedy should not grow unchecked to become more damaging than the disease. The other public interest... is that litigants should not be financially prejudiced by the unjustifiable conduct of litigation by their [opponents or their] lawyers.

The prospect of being punished for bringing a hopeless case in many ways highlights the difficulties facing the advocate. The tension between the advocate's overriding duty of frankness to the court and the duty of loyalty to the client is exacerbated by the prohibition on bringing or defending hopeless causes. The prohibition prevents the advocate from bringing an argument to the court's attention for consideration where it is wholly without merit. For an advocate to act as a pre-trial screen of doomed claims or defences places them in a position of considerable conflict by making them a preliminary judge of the issue. The duty not to take hopeless cases must also be reconciled with the duty to act for any client (the "cab rank rule") regardless of the advocate's attitude to their cause. It should also be noted that such a prohibition would seem to encourage a certain scepticism of client claims, and lack of creativity in legal argument that might not be in the best interests of the administration of justice in the long run. Moreover to require an advocate to act as such a screen requires a great deal from an advocate who may have enough trouble being retained on doubtful briefs, without requiring the advocate to wait for a retainer with better prospects for success. Perhaps most problematic is the fact that because it is open to any litigant to apply for costs against the advocate of the other side the advocate may therefore conduct the case not only in the interests of the client, and the court, but also with an eye to ensuring that no injustice is done to the other side in pursing a claim or defence.

For the advocate these are all compelling reasons to resist the court's assumption of a power to award costs against them. However, such reasoning smacks of protectionism from the perspective of the frustrated litigant who has been dragged through a protracted and costly court case in which their opponent never had any prospect of success. While the court should ensure that such sanctions are not imposed lightly, the costs that a litigant are needlessly put to ought to be borne by the wrongdoer(s) who caused them.

While such an order does act to compensate the wronged litigant, an equally interested party is the court itself. The court is concerned to ensure that it is not used as an instrument to perpetuate injustice, rather than achieve justice by the abuses of those who appear before it. The power to award costs against advocates who bring hopeless 
cases ensures that the court has the power to protect its own procedure against abuse, and control the conduct of the advocates who exercise the privilege of audience.

\section{JUSTIFICATION OF THE COURT'S SUPERVISORY JURISDICTION}

Courts exist as tribunals to which citizens may turn when they find themselves at an impasse in a dispute. The task of the court is to do justice between the parties according to the law. Unfortunately the process of the court also lends itself to other uses; delaying inevitable liabilities by mounting hopeless defences, making exaggerated allegations in the hope of a windfall payment, and employment as a platform on which to air grievances for which no legal remedy exists. Such tactics are abuses of the procedure of the court.

If the objectives of the court are to be achieved, rather than thwarted by such abuses, it is necessary for the court to be able to act immediately against the perpetrators of the abuse. One such perpetrator is the advocate who is central to the bringing of such a case. Moreover, it is the advocate's duty to advise a litigant as to the rules applicable to bringing a matter before the court and to ensure, as far as possible, that such rules are complied with. Culpability for bringing a hopeless case before the courts therefore lies with the advocate as much or more than with the litigant.

The ability of the court to sanction advocates by awarding costs against them acts as an important signal to the profession as to what standards of conduct are acceptable, and a considerable financial deterrent against breaching those standards. Such a disincentive is particularly necessary in light of the considerable pressures, from the client or from the financial pressures of legal practice, to take a case. Such a sanction ensures that the courts are equipped to be instruments of justice rather than injustice. Without an effective weapon to prevent advocates assisting in abuses of the court's process, the court would be open to be used as a tool of injustice and oppression.

At a more specific level it is important to ensure that any litigant who comes to court ought not have unnecessary costs imposed. Individuals who come (or are brought before) the court have a right to expect that the court will ensure that the process and outcome will not result in unfairness. Where a litigant is the victim of an abuse of process the opposing advocate is directly responsible. Although the proceeding is formally initiated by the other litigant, it is in practice drafted and filed by the advocate without whom the proceeding would never be brought. Where an action is inappropriately brought, or an illusory defence raised with the assistance of an advocate, the wronged litigant should be compensated for the expense to which they have been put in dismissing the abusive proceeding. If all other things were equal there would be a strong argument that the cost of such compensation should, at least in part, be borne by the wrongful litigant. However 
there are a number of reasons why, in some cases, the cost of compensating the wronged litigant should be borne by the advocate.

First, if compensation were payable by the litigant, in a number of cases such an order would be worthless due to the inability of the litigant to pay. Where there is more than one wrongdoer (ie litigant and advocate) it is inappropriate that the wronged party run the risk of the litigant being unable to meet an order for compensation. Secondly, in terms of apportioning blame the advocate is in many ways more blameworthy than the litigant. The litigant bringing the groundless action or defence is not an expert in the law, or in assessing evidence and in determining whether it will form a basis for a claim or defence. This is the task of the advocate. Moreover the advocate should be familiar with the rules of the court, and the ethical and professional duties owed to the administration of justice which override the duty of loyalty to the client. Thirdly, the advocate is an officer of the court and therefore assisting in bringing a hopeless claim or defence is perverting the ends of a tribunal of which he or she is a quasi member.

The courts have always assumed the power to govern the conduct of those who appear before them. This is particularly apposite in respect of advocates who are officers of the court. ${ }^{7}$ Where the court regulates the conduct of an advocate appearing before it, it is not only regulating its own procedure, it is also disciplining its officers. Where a hopeless case is brought with the assistance of the advocate, the advocate must either be bringing it in the knowledge that it is hopeless (and therefore assisting in an abuse), or believing that it is not hopeless (and therefore incompetent) or not caring whether it is hopeless (and therefore guilty of recklessness or gross negligence). In any of these cases the conduct of the advocate warrants action being taken by the court.

While in recent cases the courts have downplayed the disciplinary aspect of such orders, preferring to focus on the compensatory justification, ${ }^{8}$ it is still a method by which the courts are summarily disciplining advocates. Such discipline is both justifiable and necessary. Were such breaches of the duty to the administration of justice to go unsanctioned the court would be abdicating its responsibility to govern what goes on in its precincts.

7 In New Zealand both barristers and solicitors are officers of the court. The position is somewhat different in England where solicitors have historically been governed by the courts, and the courts have the power to discipline and strike names from the roll. Barristers, however, are governed by the various Inns of Court. The judges of the courts act as the final disciplinary authority as visitors to the Inns. This supervisory jurisdiction is also apparent in the court's power to enforce practitioners' undertakings. See Re Grey [1892] 2 QB 440, 443 (CA), per Lord Esher MR, Gill and McAsey v Wainui Timber Co Ltd [1992] 1 NZLR 1, 4 (CA) per Richardson J.

8 See Part VI of this article. 
Although misconduct in the conduct of litigation by an advocate falls within the disciplinary jurisdiction of the Law Society, it is still necessary for the court to act against such advocates within the course of the offending proceeding. In some cases of professional misconduct the court may also see fit to refer the matter to the District Law Society to take further action. ${ }^{9}$ While the two jurisdictions are obviously related, they are quite distinct and both remain important. The focus of the court's jurisdiction is the efficacy of its own proceeding. To ensure this it needs to have the ability to intervene in the proceeding itself rather than to defer to a separate and later disciplinary hearing of the professional body.

To rely on the disciplinary function of the professional body would have a number of potential shortcomings. Most importantly for the complaining litigant it would mean an additional proceeding to redress the injustice of the bringing of the groundless claim. Moreover the disciplinary proceedings of the District Law Societies are exactly that disciplinary. They are focused on the conduct of their members and punishing any incident of misconduct. While there is an ability to award compensation to an injured party, this is not the purpose of the proceeding and such a proceeding is an inappropriate action for a wronged litigant to seek compensation for having to defend a hopeless case. ${ }^{10}$ The complainant is not a party to proceedings before a disciplinary tribunal and the proceeding is conducted in a manner more akin to a court of inquiry than a civil proceeding. ${ }^{11}$ While it may be justifiable for matters of discipline to be considered by a professional tribunal comprised of an advocate's peers, it is not appropriate that a litigant be required to rely on such a tribunal for compensation for wrongs committed by an advocate in the course of proceedings.

The jurisdiction to award costs against advocates is justified because it is an effective measure to reduce the incidences of hopeless claims and defences being brought before the court. While the court will always be wary of denying a litigant access to the courts (as the cases discussed in this article demonstrate) where a case is meritless, and this is apparent to any competent advocate, it ought not to be brought before the court. Holding

9 This course was adopted by Hammond J in Chua $v$ ANZ above n 4, 529. Similarly in McDonald $v$ FAI (NZ) General Insurance Co Ltd [1999] 1 NZLR 583 (HC) [ McDonald v FAI], CP 507/95 the matter was referred to the District Law Society by Giles J for revision of the offending advocate's bill of costs to her client. [Editor's note: this article was submitted before the Court of Appeal heard the appeal from Giles J's decision.]

10 Law Practitioners Act 1982, ss 106(4)(e) and 112(2)(f). Section 106(4)(e) limits the amount that may be paid in compensation to any person who has suffered loss.

11 Provision is made for the representation of both the practitioner and the Society, but no reference is made to the complainant: Law Practitioners Act 1982, ss 124 and 125. 
responsible the advocate who has brought the case despite its having no prospect of success will act as a more effective deterrent than other measures that might be proposed.

Holding the litigant liable to compensate the other party where a groundless claim or defence is brought is unlikely to be effective. Where the client is insolvent and raises a hopeless defence in an effort to stave off the inevitable, a threat of an award of full costs will be irrelevant. Where the litigant is bringing a baseless claim for a collateral purpose the threat of costs will frequently be minimal in comparison to the collateral advantage which is sought. Accordingly such costs orders will be an ineffective disincentive.

It is also inappropriate to leave the wronged litigant to seek redress in another forum, be it a professional tribunal, or a further claim in court. It would run counter to the spirit and purpose of the rule prohibiting advocates from assisting in bringing hopeless cases if it were enforced by further satellite litigation, based on a wrongful claim which ought never have been brought.

It is a principle of common sense as well as justice that, where a wrong has been suffered, a remedy ought to lie against the perpetrator. It is inappropriate for a wrongdoer to shield behind a protectionist immunity. Although advocates have long enjoyed an immunity from claims against them in respect of negligence in the conduct of litigation, ${ }^{12}$ that immunity has recently been viewed with some scepticism by the courts and restricted to what is considered to be absolutely necessary to effect the policy of the unfettered administration of justice. ${ }^{13}$ The suggestion that the imposition of costs orders against counsel for misconduct or incompetence fetters the proper administration of justice to a degree that warrants the wronged litigant bearing the resulting costs is unsustainable and has been rejected by the legislature in England, ${ }^{14}$ and the courts in New Zealand. ${ }^{15}$ The words of the Sir Thomas Bingham MR in Ridehalgh $v$ Horsefield express the weakness of any argument which advocates the extension of barristerial immunity to cover costs claims: ${ }^{16}$

It is one thing to say that an advocate shall be immune from claims in negligence by an aggrieved and unsuccessful client. It is quite another for the court to take steps to rectify, at the

12 Rondel v Worsley [1967] 1 QB 443 (CA).

13 Saif Ali v Sidney Mitchell \& Co [1980] AC 198, 229 (HL) per Lord Salmon, Biggar v McLeod [1978] 2 NZLR 9, 11 (CA). A detailed argument for the abolition of such an immunity can be found in Sandra Segal "It is Time to End the Lawyer's Immunity from Countersuit" (1987) 35 UCLA L Rev 99.

14 By s 51 of the Supreme Court Act 1981 (UK).

15 McDonald $v$ FAI above $\mathrm{n} 9$.

16 Above n 6, 236. 
expense of the advocate, breaches by the advocate of the duty he owed to the court to further the ends of justice.

While the current law protects advocates against claims for negligence in the conduct of litigation, where the wrong committed is intentional, due to gross incompetence, or negligence, the policy arguments for immunity wither. It must be remembered that for every claim barred by the immunity rule there is a claimant who goes without redress. The privilege of contributing to the unfettered administration of justice is small consolation where the advocate's actions have caused considerable financial loss. Therefore where the advocate causes loss which was easily preventable (that is the loss not due to mere negligence) the advocate should be held liable to compensate those who suffered that loss.

The inherent power of the court to discipline an advocate for assisting in the prosecution of a hopeless case or mounting a hopeless defence is not an isolated power. It exists as part of the overall jurisdiction of the court to ensure that its officers act at all times properly, and that its procedures are not abused. The court will summarily discipline advocates wherever misconduct is apparent. Examples are where a retainer places the confidential information of a former client at risk, where an advocate refuses to honour an undertaking, and where reckless or unfounded allegation are made from the bar. ${ }^{17}$

Such a jurisdiction assists in the speedy and efficient delivery of justice, and demands the highest standards of conduct from advocates. Where the actions of its officers are in error, the court will move swiftly to rectify the situation. It is important that this power exists in respect of all instances of misconduct. To do otherwise would be to introduce an asymmetry into the supervisory jurisdiction of the court which would be without foundation.

\section{THE INHERENT JURISDICTION OF THE COURT}

The existence of the power to prevent its process being used for a collateral purpose or as an instrument of injustice has long been recognised. ${ }^{18}$ This is part of the inherent jurisdiction of the court. The power is one that is derived "from the very nature of the

17 Black v Taylor [1993] 3 NZLR 403 (CA), Re McDougall's Application [1982] 1 NZLR 141, 142 (HC), Gazley v Wellington District Law Society [1996] 1 NZLR 452, 454.

18 Metropolitan Bank v Pooley (1885) 10 App cas 210, 220 (HL). The power has similarly long been recognised in respect of the power to stay frivolous or vexatious proceedings: McHenry $v$ Lewis (1882) 21 ChD 202 (HC). Most recently see Ebert v Birch, The Times, April 28 1999, 34 (CA). 
court as a superior court of law"19 to ensure that they are indeed instruments of justice rather than oppression. Thus, as long ago as, 1885 Lord Blackburn stated that from early times: 20

[T]he court had inherently the right to see that its process was not abused by a proceeding without reasonable grounds, so as to be vexatious and harassing - the court had the right to protect itself against such abuse

These powers to protect against abuse, and the related duty to supervise its own officers, are the foundation for the court's power to use an award of costs to effect discipline, compensation and deterrence.

The court will always exercise its jurisdiction to ensure that the ends of justice are not thwarted by those who use its procedure for improper ends. This policy was stated in Hunter $v$ Chief Constable for the Western Midlands by Lord Diplock when observing that the case concerned: ${ }^{21}$

The inherent power which any court of justice must possess to prevent misuse of its procedure in a way which, although not inconsistent with the literal application of its procedural rules, would nevertheless be manifestly unfair to a party to litigation before it, or would otherwise bring the administration of justice into disrepute among right-thinking people.

In New Zealand the inherent power to order costs against advocates is not expressly referred to in any of the legislation or governing rules of the court. ${ }^{22}$ Other jurisdictions have chosen to extend or clarify the inherent powers of the court by articulation in legislative instruments. Thus, in England section 51 of the Supreme Court Act 1981 empowers a court to order a party's legal representative (including a barrister) to pay any

19 J Jacob "The Inherent Jurisdiction of the Court" [1970] CLP 23, reprinted in J Jacob The Reform of Civil Procedural Law (Sweet \& Maxwell, London, 1982) 224. New Zealand Social Credit Political League $v$ O'Brien [1984] 1 NZLR 84 (CA) is the leading New Zealand authority.

20 Metropolitan Bank v Pooley above n 18, 220.

21 [1982] AC 529, 536 (HL), applied in Christensen v Peat Marwick [1994] 3 NZLR 745 (HC). It is of note that some commentators have referred to the power as one of a "superior court" (see Jacob, above n 19). However, the current view is that any court has the power to prevent an abuse of its own procedure by making orders against advocates.

22 Rule 46 of the New Zealand High Court Rules gives the court a broad discretion in respect of the award costs which have been construed as allowing costs orders against advocates: $Y v M[1994] 3$ NZLR 581 (HC). Section 16 of the Judicature Act 1908 preserves the inherent jurisdiction of the High Court that it had prior to the passing of the Act. The jurisdiction has been applied in respect of costs against advocates: Stephens v Stephens [1991] 1 NZLR 633 (HC), Utah Construction and Mining Co v Watson [1969] NZLR 1062 (CA). 
costs which are wasted through that representative's improper, unreasonable or negligent conduct (frequently called "wasted costs orders"). ${ }^{23}$

The English provisions and the cases decided under them are relevant to the New Zealand context. The approach of the English Court of Appeal in the leading English case of the provisions of Ridehalgh $v$ Horsefield ${ }^{24}$ has been adopted by the High Court of New Zealand in McDonald $v$ FAI. $^{25}$ Ridehalgh discusses the provisions in terms of a compensatory principle which is of direct relevance in the New Zealand situation.

The United States position is typified by Rule 11 of the Federal Rules of Civil Procedure (which is reflected in many States). ${ }^{26}$ That rule provides that an attorney in making any representation to the court warrants that the action is not improper, that the arguments of law are made in good faith, and the factual allegations and denials have a credible basis. ${ }^{27}$ In the event that the rule is breached the court has wide disciplinary powers. ${ }^{28}$

23 The relevant part of $\mathrm{s} 51$ provides:

(6) In any proceedings mentioned in subsection (1), the court may disallow, or (as the case may be) order the legal or other representative concerned to meet, the whole of any wasted costs or such part of them as may be determined in accordance with rules of court.

(a) as a result of any improper, unreasonable or negligent act or omission on the part of any legal or other representative or any employee of such a representative; or

(b) which, in the light of any such act or omission occurring after they were incurred, the court considers it is unreasonable to expect that party to pay.

Similar provisions in respect of the conduct of criminal cases can be found in the Prosecution of Offences Act 1985, s 19A. The jurisdiction is expounded in J Holland (ed) Cordery on Solicitors (9 ed, Butterworths, London, 1996) particularly Section 10. See also Steven Fennel "Wasted Costs after the Courts and Legal Services Act " [1993] Professional Negligence 25.

24 Ridehalgh $v$ Horsefield above $\mathrm{n} 6$.

25 McDonald v FAI above n 9, 592.

26 For a good analysis of the rule and its policies, see Michael Mazurczak "Critical Analysis of Rule 11 Sanctions in the Seventh Circuit" (1988) 72 Marquette L Rev 91.

27 In particular $\mathrm{r} 11(\mathrm{~b})$ provides:

By presenting to the court (whether by signing, filing, submitting, or later advocating) a pleading, written motion, or other paper, an attorney or unrepresented party is certifying that to the best of the person's knowledge, information, and belief, formed after an inquiry reasonable under the circumstances,

(1) it is not being presented for any improper purpose, such as to harass or to cause unnecessary delay or needless increase in the cost of litigation; 
While the older cases refer to orders of costs against solicitors who are traditionally answerable to the court, courts have recently awarded costs against counsel as well as solicitors. This approach is particularly appropriate in New Zealand in light of the fact that practitioners are free to act as solicitors and/or barristers, and there is no independent governance of practitioners who act as barristers. There appears little justification for exempting barristers from the disciplinary powers of the court when the wrongs committed are no different in kind or degree from those of solicitors which have always incurred the sanctions of the court.

\section{COSTS AGAINST ADVOCATES GENERALLY}

The situations in which the court will make an order of costs against an advocate vary and are not closed. While misconduct often exists, and in many cases the conduct of the advocate is reprehensible, this need not be the case. Where there is an error that shows a lack of competence (not just a lack of judgement) or negligence in a failure to attend to routine matters the court may make an order.

Some cases are clear. In Kamo Sports \& Dive Ltd $v$ Harrison Sports (Kamo) Ltd ${ }^{29}$ counsel for the plaintiffs sought to introduce new expert evidence at the trial when timetable orders which had allowed for the exchange of briefs of evidence had not been complied with. The default was solely the fault of counsel. In ordering costs Fisher J stated that "the time has come for the Courts to blow the whistle on non-observance of pretrial directions" 130 and ordered counsel to pay the increase in the costs of the defendant which had been caused by the non-compliance. Similarly, inexcusable delay in taking steps

(2) the claims, defences, and other legal contentions therein are warranted by existing law or by a nonfrivolous argument for the extension, modification, or reversal of existing law or the establishment of new law;

(3) the allegations and other factual contentions have evidentiary support or, if specifically so identified, are likely to have evidentiary support after a reasonable opportunity for further investigation or discovery; and

(4) the denials of factual contentions are warranted on the evidence or, if specifically so identified, are reasonably based on a lack of information or belief.

28 Rule 11(c)(2) provides:

the sanction may consist of, or include, directives of a non-monetary nature, an order to pay a penalty into court, or, if imposed on motion and warranted for effective deterrence, an order directing payment to the movant of some or all of the reasonable attorneys' fees and other expenses incurred as a direct result of the violation.

29 (1993) 7 PRNZ 321 (HC).

30 Kamo Sports \& Dive Ltd v Harrison Sports (Kamo) Ltd above n 29, 324. 
which puts the other side to expense will be sufficient reason for such an order. ${ }^{31}$ However the older test of gross negligence or serious dereliction of duty ${ }^{32}$ has been discarded in favour of an approach which is more focussed on the unfairness of the other party bearing the costs which have been needlessly incurred. ${ }^{33}$

Where the failure in the conduct of the litigation cannot be laid at the door of the client it is inappropriate to tax the client with costs and the court will order costs against the advocate. Thus if a case is commenced without the actual authority of the litigant (through error or otherwise) the courts have ordered that costs be paid by the legal representative. ${ }^{34}$ Where the case is in reality brought by the legal representative and in substance amounts to champerty (where the named party is a mere puppet), the legal representative will be similarly liable for costs. ${ }^{35}$

In cases where there has been serious misconduct by the advocate in the conduct of the hearing the court will use an order of costs to indicate the unacceptability of such conduct. In such cases the misconduct is often linked with hopeless defences or doomed claims. Chua $v \mathrm{ANZ}^{36}$ is a case where the advocate sought to frustrate a mortgagee sale by raising unfounded defences. In the course of making an application for an ex parte injunction he knowingly misled the court. In the words of Hammond J: ${ }^{37}$

This appears to me to be a case in which Mr Middleton has put his zeal for his clients' interests ahead of his plain duty of candour to the court. On the evidence before me I have to say that he actively misled the court on 24 October.

This resulted in an order of costs against counsel (but not the instructing solicitors).

The court will also award costs where the advocate has failed to take reasonable measures to ensure that the litigant has adequately complied with orders of the court (for example in respect of interrogatories and discovery). The court will ensure that the costs incurred by such a failure are borne by the legal adviser. Thus in the leading case of

31 Sinclair-Jones $v$ Kay [1989] 1 WLR 114 (CA) where a delay in applying to set aside a default judgment of liability meant that the plaintiff needlessly prepared submissions as to quantum.

32 Myers v Elman [1940] AC 282 (HL).

33 Kamo Sports \& Dive Ltd v Harrison Sports, above n 29, 324.

34 Newbiggin-by-the-sea v Armstrong (1879) 13 ChD 310 (CA).

35 In re Jones (1870) 6 Ch App Cas 497, 499 (CA).

36 (1997) 11 PRNZ 523 (HC).

37 Above $\mathrm{n} 36,529$. It is of note that Hammond J also took the step of drawing the conduct of counsel in this case to the attention of the District Law Society. 
Myers $v$ Elman $^{38}$ the defendant's solicitors had failed to carefully advise the defendant of the scope of the discovery which was necessary. The court held that the extra costs incurred ought to be borne by the solicitor in question. Moreover, in that case although the affidavit in question was completed by a managing clerk of the office the solicitor was held responsible for the clerk's misconduct.

If it becomes clear that there is no real likelihood of success of a claim or defence when new evidence comes to hand (for instance by discovery) the advocate may be obliged to amend the pleadings accordingly, or possibly to discontinue a claim. Thus in Edwards $v$ Edwards ${ }^{39}$ it was held by the court that the continued prosecution of a claim that a husband was wilfully neglecting his wife was unreasonably continued once the documents discovered by the husband made it clear that the claim was unsustainable. Sachs $J$ stated that it was the duty of legal advisers to: ${ }^{40}$

examine closely whatever is disclosed on his opponent's affidavit of documents to see whether the relative prospects of success or failure have been altered thereby.

The duty is not merely one to use good faith, or best endeavours. Rather the decision to proceed after discovery must be tested against the judgment of a reasonable adviser who investigated the facts with proper care. ${ }^{41}$ This amounts to a duty not to pursue a hopeless case.

\section{THE COMPENSATORY JUSTIFICATION}

The theoretical basis of the power to award costs against advocates is the right of the court to govern its own procedures. However, the orders are motivated by a desire to ensure that litigants do not suffer loss by the misconduct of an opposing advocate. There are also hints in the cases that the judges also seek to set an example and to deter other advocates from misconducting themselves. ${ }^{42}$ These three objectives of such orders, punitive, compensatory, and deterrent, are not necessarily inconsistent. While the inherent power of the court to govern its procedures seems to lend itself most readily to

$38 \quad$ Above $\mathrm{n} 32$.

39 [1958] P 235. In this case the court also took note of the fact that the solicitors for the wife had needlessly required voluminous information which caused considerable wasted expenditure.

40 Above n 39, 252-253.

41 Above n 39, 255.

42 See the "warning sounded" by Thomas J in Henricksen v Grierson Jackson Securities Pukekohe Ltd (1992) 2 NZ Conv Cas 191-419, 191-442 (HC), and Fisher J "blowing the whistle" on advocate failures in Kamo Sports \& Dive Ltd v Harrison Sports (Kamo) Ltd above n 29. 
the punitive aspect of the jurisdiction, there has been a steady judicial and legislative trend to emphasise the compensatory justification.

Prior to the overhaul of this area of the law in England, the courts had considerable difficulty justifying the jurisdiction without stating outright that the motive was compensatory. Even in the leading case of Myers $v$ Elman ${ }^{43}$ members of the House of Lords seemed to differ on the matter. Viscount Maugham stated that the primary object of the power was not to punish, but to protect the client, and indemnify the party who has suffered loss. ${ }^{44}$ Lord Atkin framed the power as an adjunct of the duty of the advocate to conduct litigation with propriety, ${ }^{45}$ while Lord Wright sought a balance by stating that the jurisdiction was not merely punitive but also compensatory. ${ }^{46}$

Subsequent courts have generally equivocated on the matter. ${ }^{47}$ The English position has been resolved by the intervention of statute. ${ }^{48}$ In McDonald $v$ FAI ${ }^{49}$ Giles J chose to adopt the philosophy behind the English approach. In emphasising the compensatory function of the jurisdiction he observed that the jurisdiction: ${ }^{50}$

...is necessary to ensure justice overall. It is available to the Court as a means of ensuring, in the appropriate case, that a litigant should not be financially prejudiced by unjustifiable conduct of litigation by counsel.

It is, however, clear that for the jurisdiction to award costs to be invoked there must have been a serious lapse by the advocate which amounts to more than mere negligence. ${ }^{51}$ Thus a disciplinary element remains.

43 Above $n 32$

44 Above $\mathrm{n} 32,282$.

45 Above $\mathrm{n} 32,302$.

46 Above n 32, 319.

47 See: Mauroux v Soc Com Abel Pereria Da Fonesca SARL [1972] 1 WLR 962, 970 (HC) ("primarily compensatory"); Currie \& Co $v$ The Law Society [1977] QB 990, 997 ("both punitive and compensatory"). These cases are reviewed in Davey Chiesman v Davey Chiesman [1984] Fam 48, 61 (CA) per May LJ who took adopted the Currie \& Co approach.

48 Under the English statutory powers contained in s 51 of the Supreme Court Act 1981 it is clear that there is a compensatory motive behind such orders. See Re A Barrister (Wasted Costs Order) [1993] QB 293, 301 (CA), Ridehalgh $v$ Horsefield above n 6, 227.

49 Above $\mathrm{n}$ 9. The court adopted the approach in Ridehalgh $v$ Horsefield (above $\mathrm{n}$ 6) in which a distinction was made between the compensatory wasted costs orders, and the disciplinary function of the courts.

50 Above n 9, 591.

$51 Y v M$ above $\mathrm{n} 22$ 
The courts have been wary of stating outright that bringing a hopeless case amounts to misconduct in respect of which costs will be ordered against an advocate. This has led to an uneasy equivocation whereby it appears that the courts will intervene only when a hopeless case amounts to an abuse of process. Thus in Ridehalgh $v$ Horsefield the English Court of Appeal took the view that bringing a hopeless case is not per se improper, unreasonable or negligent in terms of section 51 of the Supreme Court Act $1981 .^{52}$ The court relied on the observations of Lord Pearce in Rondel $v$ Worsley: 53

It is easier, pleasanter, and more advantageous professionally for barristers to advise, represent or defend those who are decent and reasonable and likely to succeed in their action or their defence than those who are unpleasant, unreasonable, disreputable and have an apparently hopeless case. Yet it would be tragic if our legal system came to provide no reputable defenders, representatives, or advisers for the latter.

Those words were, however, spoken in defence of an advocate's immunity in respect of actions taken in the prosecution of litigation. They refer specifically to the policy basis behind the cab rank rule and its relationship with barristerial immunity from claims for negligence by lay clients. The statement does not refer to liability for costs for misconduct. Moreover, Lord Pearce in Rondel identifies the need for advocates to take apparently hopeless cases. This suggests a case which might on first blush appear hopeless, but in fact has some prospect of success. ${ }^{54}$ It is suggested that the claim in Ridehalgh $v$ Horsefield that a litigant may reject an adviser's advice that a case is hopeless and insist that it be litigated is ill founded. ${ }^{55}$

Ridehalgh does, however, note that there are hopeless cases that will amount to an abuse of process. To assist in the prosecution of such a case would be misconduct which falls foul of the wasted costs rules. Sir Thomas Bingham MR acknowledged that the distinction between a legitimate hopeless case, and one which amounts to an abuse is difficult to define. It is, however, suggested that no such meaningful distinction can be

52 Ridehalgh $v$ Horsefield above $\mathrm{n} 6,227$.

53 Above n 12, 275.

54 There is a tendency in the cases and commentary to qualify the term "hopeless" with words such as "truly" or "absolutely". This can erroneously suggest that there are degrees of hopelessness. Hopeless is an absolute term. It is not possible for one case to be more hopeless than another. However, qualifiers such as "apparently" or "demonstrably" are meaningful as they refer to collateral matters such as whether a case superficially appears hopeless or can be shown to be hopeless. Accordingly I have attempted to avoid using terms such as "truly hopeless".

55 Ridehalgh $v$ Horsefield above n 6, 234. 
made. If a case is hopeless it is not motivated by a desire to obtain court awarded relief, and must therefore be motivated by some collateral purpose. The only exception to this would be where a case is pursued in the mistaken belief that it has some prospect of success when it is hopeless. Such an error suggests incompetence, itself sufficient reason to invoke the power of the court to award costs against the advocate.

The power of a court to punish an advocate for assisting in the maintenance of a hopeless case presumes that such cases should be denied a court hearing. The exclusion of a claim from the courts is a serious step which runs counter to the stated object of the courts to make it as easy as possible for litigants to have access to them. It is important, then, that any rule excluding prospective litigants should be as clear as possible, and that in cases of doubt it should be presumed that the case is not hopeless.

There are two ways in which a case might be considered hopeless: either the facts upon which the claim depends may be wholly unsustainable, or, while the facts pleaded may be provable, they may give rise to no recognised arguable action. Each of these kinds of hopelessness (and they are not exclusive) raise problems of their own.

\section{A Hopeless Facts}

The advocate is not a fact-finder. The primary task of an advocate in our judicial system is to present the client's case in the best light possible. They are not therefore to usurp the court's role in determining the credibility of witnesses, or the inferences which may be drawn from the evidence. This said, they are not allowed to assume the truth of their clients' evidence in an uncritical manner. One example of a case which, from the report, appears as much ridiculous as hopeless, but in which the advocate was not found to have acted improperly, is Orchard v South Eastern Electricity Board. ${ }^{56}$ The plaintiffs in this case occupied a house which suffered from poltergeist-like phenomena. Patches of water would appear in areas of the house, especially around electricity sockets, and items of furniture would move. The plaintiffs claimed that these phenomena were due to an escape of electricity which caused water to vaporise and reappear as the patches of water. The escape similarly caused static build-ups which in turn caused the furniture to move. Perhaps most surprising is the fact that these allegations were supported by the evidence of an independent expert. It transpired that the phenomena were the result of actions by the plaintiffs' 15 year old son.

In that case the balance that an advocate must achieve in respect of the veracity of their client's assertions was stated by Sir John Donaldson MR.57

56 [1987] QB 565 (CA).

57 Orchard v South Eastern Electricity Board above n 56, 572. 
[I]t must never be forgotten that it is not for solicitors or counsel to impose a pre-trial screen through which a litigant must pass before he can put his complaint or defence before the court. On the other hand no solicitor or counsel should lend his assistance to a litigant if he is satisfied that the initiation or further prosecution of a claim is mala fide or for an ulterior purpose or, to put it more broadly, if the proceedings would be, or have become, an abuse of the process of the court or unjustifiably oppressive.

In approaching the issue of whether the advocate has acted wrongly the court also emphasised the importance of not imposing the wisdom of hindsight on a decision made with limited information. In Orchard the Court of Appeal adopted the reasoning of Steyn $\mathrm{J}$ in the court below which noted that the solicitors and counsel for the plaintiff brought the action on the basis of independent observations of the phenomena and an expert report which supported the claim. The fact that at trial a key witness was rejected as wholly unreliable did not impugn the conduct of solicitors or counsel in presenting the case based on that evidence to the court.

In contrast to Orchard is Tolstoy-Miloslavsky $v$ Aldington. ${ }^{58}$ In that case the plaintiff had formerly been successfully sued by the defendant for libel and a significant order for damages and costs had been made against him. In this action (which was brought some four years after the initial case) the plaintiff sought to have the earlier judgment set aside on the ground of fraud. It was held by the court that none of the evidence presented to the court was capable of establishing the fraud relied on, and that the action was brought solely to impugn the findings in the earlier case. It was found that the proceeding was "utterly hopeless" and an abuse of the process of the court. ${ }^{59}$ Moreover it was observed that solicitors were not entitled to rely uncritically on the advice of counsel that a claim was sustainable but had to exercise their own judgment in accepting such advice. ${ }^{60}$ The court found that the bringing of the action was wholly unjustified and that the assistance of the legal advisers showed a lack of due propriety which warranted an order of costs against them.

The distinction between Orchard and Tolstoy appears to be the fact that in the former, had the court believed the plaintiffs' witnesses, it was possible that they might find in favour of the plaintiffs. Moreover, the court will not question an advocate's decision to rely on the evidence of an expert. By contrast in Tolstoy the evidence adduced by which the plaintiff sought to impugn the findings of the earlier court were incapable of establishing the case pleaded and consequently on the information available to the

59 Tolstoy-Miloslavsky $v$ Aldington above n 58, 747.

60 Tolstoy-Miloslavsky $v$ Aldington above n 58, 747. 
advocate it could be demonstrated that the case was hopeless. Moreover in matters of law and legal practice a legal representative may not, by relying on the advice of another, divest themselves of their responsibility to conduct litigation responsibly. There were also aggravating factors in Tolstoy. The court was firm in its view that the action was brought to attack a previous final decision of the court and was therefore an abuse. Orchard is distinguishable because there the claim, though "weird" (in the words of the court), was brought in good faith.

Where a client has made allegations which are unfounded, the court will be slow to punish an advocate for taking the client at their word. While an advocate should not bring a case if they are certain that it is ill founded, they are entitled to make their own judgment as to their client's veracity. If the advocate in question suffers a failure of judgment this does not amount to improper conduct or incompetence and therefore intervention by the court is inappropriate. In $Y v M^{61}$ a practitioner filed an affidavit in the Family Court which contained allegations of sexual abuse by a father of a child which transpired to be quite unfounded. While the court took the view that the filing of the affidavit was inappropriate, it was held that it was due to a lack of the proper degree of caution, unquestioning acceptance of the word of the mother, and the advocate's lack of a degree of scepticism of her client's version of events. In $Y v M$ there was a degree of urgency to the case which meant that a full investigation was not possible. It was held that this was more an error of judgment than incompetence or misconduct and costs would not be awarded against the advocate. ${ }^{62}$

\section{B Hopeless Law}

Lawyers (and particularly academics) spend most of their time dwelling on areas of the law which are doubtful or vague. However, many areas of the law, and particularly statute law, are exceedingly clear. Cases where the courts have imposed sanctions against advocates for legally hopeless claims generally involve the application of statute law. Not only is there less latitude for interpretation in respect of legislation, but also in the case of statutes, the courts have no power to amend or overrule. ${ }^{63}$

61 Above $\mathrm{n}$ 22. The duty not to admit evidence of serious allegations unless the advocate is satisfied that the making of such an allegation is justified on the facts of the case is also found in $r 8.05$ of the Rules of Professional Conduct of Barristers and Solicitors. See also Gazley $v$ Wellington District Law Society [1996] 1 NZLR 452, 454 (High Court sitting with a full panel of three judges).

62 Following $R$ \& $T$ Thew Ltd $v$ Reeves (No 2) [1982] QB 1283, 1286 (CA).

63 This of course varies between jurisdictions. However the doctrine of parliamentary supremacy by which the courts are unable to amend or overrule legislation passed by Parliament is in full force in both New Zealand and the United Kingdom. 
In Da Sousa v Minister of Immigration ${ }^{64}$ it was found that an application for entry permits, and the application for review subsequent on the refusal of entry, was doomed to fail. Moreover, "to a legal practitioner familiar with the provisions of the Act and Regulations there should have been no doubt that ... Mrs Da Sousa did not qualify for the grant of such permits". ${ }^{65}$ In Da Sousa French J followed the English authorities, including Orchard, in noting that it was not the fact that the claim failed which led to an order of costs being made against the advocate, but the fact that the bringing of the action amounted to a serious dereliction of duty. The application amounted to such a dereliction because it reflected "a serious failure to give reasonable attention to the relevant law and the facts". 66

Da Sousa was relied on in New Zealand by Giles J in McDonald v FAI (NZ) General Insurance Company Ltd. ${ }^{67}$ The facts giving rise to that case are complex. The plaintiff was a victim of the fraud of a former solicitor who had since been bankrupted. Compensation for losses suffered at the hands of the former solicitor was sought from the solicitor's insurer, and the Law Society. The claim for costs against the advocate was made in respect of the claim against the insurer ${ }^{68}$ which failed on a number of counts. ${ }^{69}$ In light of these failures the court found that "there really never was any prospect whatever of

$64 \quad$ (1993) 114 ALR 708 (FCA).

Da Sousa v Minister of Immigration above n 64, 710 .

66 Da Sousa v Minister of Immigration above $\mathrm{n} 64,713$.

67 McDonald v FAI above $\mathrm{n} 9$

68 Although there was considerable concern by the court of the conduct of the claim against the Law Society including the refusal of a settlement offer paid into court, without clear instruction from the client, of a sum which far exceeded the final award.

69 The central argument of the plaintiff was that s 9 of the Law Reform Act 1936 (which provides that if a contract of insurance indemnifies the insured against damages the party in whose favour the damages have been awarded has a charge over any insurance money payable which is recoverable by that party by a court action against the insurer). That argument failed because it:

- ignored the fact that the contract of insurance did not cover the loss claimed because the amount claim was due under a guarantee and this was not a risk covered by the contract of insurance; and

- relied on the existence of a second policy of insurance to an innocent member of the firm, however, no such policy existed; and lastly

- $\quad$ all insurance was obviously voidable for material non disclosure as all the insured parties had failed to disclose knowledge of the frauds which had occurred. 
success against FAI". ${ }^{70}$ In reviewing the authorities Giles J rejected counsel's contention that the court's jurisdiction to award costs against legal advisers is restricted to solicitors.

In looking to the recent English authorities his Honour noted that they were applying the statutory wasted costs regime. However, the tests applied were held to be relevant. This meant that the older test of "serious dereliction" found in Myers $v$ Elman ${ }^{71}$ was abandoned in favour of a lower test which is best expressed in the Giles J's own words: ${ }^{72}$

The wasted costs jurisdiction does not require serious professional misconduct. Mistake or error of judgment will not justify an order, but misconduct, default or even negligence is enough if that negligence is serious or gross. Neither will the fact that the case was lost be enough. All the circumstances have to be looked at. The jurisdiction is compensatory not punitive, but if the facts cry out for a remedy (as they do here) then the jurisdiction exists.

In McDonald $v$ FAI the advocate was pressing the hopeless case without the fully informed consent of the client. Giles J stated that if the client is informed of the hopelessness of the case and instructs the legal adviser(s) to continue then no misconduct is involved. This stance was taken relying on the reasoning of Sir Thomas Bingham MR in Ridehalgh $v$ Horsefield ${ }^{73}$ which was in turn based on the words of Lord Pearce in Rondel $v$ Worsley ${ }^{74}$ which concerned a quite different issue. ${ }^{75}$ With respect, this seems to be at odds with the principle underlying the court's jurisdiction to award costs. If a case can be shown to be hopeless the advocate is not assisting a client in bringing a case for vindication of a legal right by a court order in their favour (or rejecting a claim based on a legitimate defence). The motivation for such a claim or defence must be collateral to the proceeding itself. Bringing a case for such a purpose amounts to an abuse to which an officer of the court must never be a party.

This approach is reflected in the older case of Edwards $v$ Edwards ${ }^{76}$ which was cited by Giles $\mathrm{J}$ in FAI. There, facts were available to the wife who was the plaintiff in a matrimonial action for wilful neglect which showed that the case was doomed to fail. This information was available to her legal advisers only after discovery by the husband.

70 McDonald v FAI above n 9, 587.

71 Above $\mathrm{n}$ 32, and applied in numerous subsequent cases, see Abraham $v$ Jutsun [1963] 1 WLR 658 (CA).

72 McDonald v FAI above n 9, 592

73 Above n 6, 234

74 Above $\mathrm{n} 12$ and text accompanying.

75 Followed in S v M (1998) TLR 201 (HC).

76 [1958] P 235. 
Before that information was in the hands of the legal advisers their actions were unimpeachable. However, it was held that to continue the action on the instructions of the wife in the face of this evidence amounted to a failure for which the costs could be awarded against the legal advisers. The fact that the client is aware of the hopelessness and consents to the continuation of the action cannot release the advocate of their duty to the court not to assist in abusing its process for a collateral purpose. ${ }^{77}$

\section{Novel Arguments}

There is a distinction between a case which is wholly without legal merit, and a case for which no precedent exists, or for which a contrary precedent exists. There are numerous examples of cases in which an advocate has successfully argued that the court ought to depart from existing law, or create a new rule. The mounting of a novel legal argument is not of itself misconduct, even if the judge who hears it refuses to extend the law in the way suggested. Indeed in Abraham $v$ Jutsun Lord Denning MR noted that it is an advocate's "duty to take any point which he believed to be fairly arguable on behalf of his client. The advocate is not to usurp the province of the judge". ${ }^{78}$ There are, however, two kinds of situation where an argument that is not consistent with existing law may amount to misconduct: if the advocate misleads the court as to the law, or if the argument is so without foundation as to show bad faith or incompetence on the part of the advocate. ${ }^{79}$

The statement of Lord Denning MR in Abraham v Jutsun was mitigated with the caveat that it is improper for an advocate to present the law to the court as something it is not. Thus when making an argument against authority, the existence of the contrary authority must be brought to the attention of the court. Harman LJ took a similar stance noting that it cannot be misconduct merely to take a bad legal point unless the advocate knows that the argument is flawed and conceals the flaw from the court. ${ }^{80}$ It has similarly been held to be improper conduct to ignore contrary precedent and to cite misleadingly from cases. $^{81}$

77 See also Tolstoy-Miloslavsky $v$ Aldington, above $\mathrm{n} 58$ where the plaintiff was clearly aware of the lack of merit of the claim and the motivation behind the action. However the legal advisers were held liable for assisting in an action which amounted to an abuse of the process of the court.

78 Abraham $v$ Jutsun, above $\mathrm{n} 71,663$, followed in Utah Construction and Mining Co $v$ Watson above $\mathrm{n}$ 22,1065 .

79 As to the duty to put all relevant authorities before the court see rule 8.01 of the Rules of Professional Conduct for Barristers and Solicitors including cls 4 and 5 of the commentary.

80 Abraham v Jutsun, above n 71, 663.

81 A-Abart Electric Supply, Inc v Emerson Electric Co (1992) 956 F2d 13997 Cir (decided under r 11 of the Federal Rules of Civil Procedure). 
Any novel argument mounted must have a degree of merit to it. It must be conceivable that a court would agree with the submission. It must therefore be within the jurisdiction of the court to make the order sought. Moreover it must be possible for the argument made to lead to the order sought. If the application is wholly misconceived, ${ }^{82}$ or simply fallacious ${ }^{83}$ it demonstrates a degree of incompetence on behalf of the advocate which warrants the court ordering costs against them. Similarly if the arguments which are put forward also serve a collateral purpose such as the delaying of the inevitable exercise of remedies the court will give a short shrift to the advocate who makes them. ${ }^{84}$ Some assistance may be gained from rule 11 of the Federal Rules of Civil Procedure. ${ }^{85}$ Part of that rule provides that in representing a matter before the court the attorney warrants that:

the claims, defences, and other legal contentions therein are warranted by existing law or by a non-frivolous argument for the extension, modification, or reversal of existing law or the establishment of new law;...

The test of non-frivolousness is an objective one which does not rely on the good faith of the advocate. ${ }^{86}$ The notes of the advisory committee to the rules suggest that any legal argument must be based on a "plausible" view of the law. ${ }^{87}$ If an argument has no basis in existing law and no realistic argument can be made that the law should be changed, sanctions will be imposed. ${ }^{88}$ If the advocate can show that reasonable research was done into the point of law that is being argued this will assist in showing that the argument is non-frivolous. The mere fact that after research a mistake as to the law is made that would have been revealed with extended research will not, of itself, be enough for an order to be made.

In McDonald $v$ FAI, ${ }^{89}$ while it was accepted that there will be cases where the boundaries of the law must be tested, and that litigants will often pursue tenuous claims

82 As in Da Sousa $v$ Minister of Immigration, above $\mathrm{n} 64$.

83 As in McDonald $v$ FAI, above $\mathrm{n} 9$.

84 Henrickson v Grierson Jackson Securities Pukekohe Ltd above n 42.

85 See above $\mathrm{n} 27$ and 28.

For a useful discussion of this aspect of the rule see Nancy Burger-Smith "Avoiding Sanctions Under Federal Rule 11: A Lawyers Guide to the 'New' Rule" (1989) 15 William Mitchell L Rev 607.

See also Hurd v Ralphs Grocery Co (1987) 824 F2d 8069 Cir.

88 Gutterman v Eimicke (1989) 125 FRD 3482 Cir (EDNY) 
which are abandoned before trial, the arguments were barred by the clear words of the statute and unequivocal law.

In Ridehalgh $v$ Horsefield ${ }^{90}$ the solicitor-advocate erred in a fundamental aspect of the case. However the error was not considered serious enough to invoke the wasted costs jurisdiction of the court because the law involved was complex, the authoritative works in the area gave no clear answer to the issue, the matter was a minor one and they were not specialists in the area, a judge in a lower court made the same mistake, counsel for the opposing party acceded to a consent order based on the mistaken point of law, and the final judgment on the point was reached only after two days argument and a reserved judgment. Thus even though the point taken was clearly and demonstrably wrong after thorough investigation, the level of complexity involved showed that the argument was not frivolous, and that a competent solicitor could reasonably make such an argument.

\section{Impecunious Clients}

There are numerous instances where a successful litigant will be justifiably aggrieved that an action was brought against them and they are denied recompense due to the impecuniosity of the unsuccessful party. The courts have, however, been wary of placing responsibility at the door of legal advisers in all cases. However, the fact that a litigant is impecunious, even if the case is a doubtful one, is not to be held against the legal adviser. Such a stance would reduce the availability of legal assistance to those without funds even further as there would be additional risk imposed on any legal adviser that chose to act. This was pointed out by Barker J in Poa $v$ Cornwell $^{91}$ where it was noted that the appropriate cause of action for a defendant in such a case was to seek security for costs prior to trial. Where an indigent party complains of a wrong, the court should be careful to ensure that the lack of funds does not impede the ability to seek redress from the courts.

Similarly irrelevant to the question of costs being awarded against an advocate is whether the litigant is in receipt of legal aid. While the ability to recover costs against a legally aided litigant who is unsuccessful is severely limited, ${ }^{92}$ the bringing of a legally aided claim that fails suggests, of itself, no misconduct by an advocate. Even a failure by an advocate to comply with the requirement to inform the other side that their client is

90 Above n 6, 244. For a US equivalent where the research was inadequate see Crookham v Crookham (1990) 914 Fd 10277 Cir.

91 (1995) 8 PRNZ 588 (HC).

92 Legal Services Act 1991, ss 86 and 87. 
legally aided has been held not to warrant an order of costs. ${ }^{93}$ Such an omission cannot be said to have caused the other party any loss, and in any event it is an oversight of too minor a nature to warrant sanction. The relationship between legal adviser and a legally aided client should be the same in all respects other than liability for costs. As Sir Thomas Bingham MR observed in Ridehalgh $v$ Horsefield ${ }^{94}$ the legal representatives of a legally aided client:

...must bear prominently in mind that their conduct should not be tempered by the knowledge that their client is not their paymaster, and so not, in all probability, liable for the costs of the other side.

Perhaps more problematic is the situation where a legal adviser acts without fee in a hopeless case. In general pro bono work is to be commended. However where the pro bono work amounts to assisting in an abuse of the process of the court this seems to compound the misconduct. This problem had to be addressed by the court in TolstoyMiloslavsky $v$ Aldington ${ }^{95}$ where the legal advisers acted without fee. The court, however, separated the fact that the case had been taken without fee, and the fact that it was hopeless and an abuse. It was held that as a matter of policy the court should encourage pro bono work, and as such it was not a relevant consideration in considering the conduct of the legal advisers. In particular a legal adviser who acts without fee should not be treated as a maintainer of an action and liable for costs on that basis. ${ }^{96}$

\section{E Client Failure}

There are occasions where one party to an action is put to considerable expense by the manner in which the case is conducted. However, this is not always able to be laid at the door of the legal adviser. In one of the six cases which were consolidated in Ridehalgh $v$ Horsefield, Antonelli $v$ Wade Gery Farr, ${ }^{97}$ a barrister accepted instructions six days before trial. The brief itself was not delivered at all, and only meagre papers were ever in the hands of the barrister. This was due to the failure of the client to attend to pre-trial matters. The trial judge had held that it was improper to accept a brief at such short notice and this had caused wasted costs. On appeal this finding was overturned. It was noted that the barrister was obliged by the rules of conduct to accept any instructions that

93 Maroux v Soc Com Abel Pereria Da Fonesca SARL above n 47, also Roberts v Coverite (Asphalters) Ltd reported in Ridehalgh $v$ Horsefield above n 6, 247.

94 Above n 6, 235.

95 Above $\mathrm{n} 58$

96 Above n 58, 746.

97 Above n 6, 264 
were within her area of expertise and which she was available for. Her action in taking the case at such short notice could not therefore be said to amount to misconduct. Moreover there will be instances where for one reason or another a client finds themselves without a legal representative at the last moment. The court should not make it more difficult for such litigants to gain assistance in such cases.

Similarly where delays or omissions are due to client rather than lawyer default there can be no suggestion of misconduct by the lawyer. Thus if a client fails to respond to an offer, or give instruction to their legal representative, no order of costs ought to be made against the legal representative due to the consequent delays or costs. ${ }^{98}$ In such cases any extra costs incurred are due to the inaction of the client rather than any action of the advocate. While costs may have been wasted, these ought properly to be laid at the door of the client rather than their legal adviser.

\section{F No Duty to the Other Side}

The sanction imposed where an advocate misconducts themselves in the course of litigation is invariably an order that they pay the costs of the opposing litigant. The fact that the order serves to compensate the other litigant for the expense to which they have been put by the advocate's misconduct appears to suggests that an advocate has a kind of duty to the other side in the conduct of litigation. Such a view gains support from the words of Lord Denning MR in Kelly $v$ London Transport Executive ${ }^{99}$ where he suggested that, at least when an advocate acts for a legally aided client, there is a duty to the other side not to put them to needless trouble or expense. This was based on dicta in the old case of Re Jones in which Lord Hatherly LC stated that: ${ }^{100}$

However anxious a solicitor may be in the execution of his duty, I think it the duty of the court to be equally anxious to see that solicitors not only perform their duty towards their clients, but also towards all those against whom they are concerned, and that care should be taken to see that the litigation is the bona fide litigation of the client and not a litigation carried on altogether on the solicitor's account.

This is, however, weak authority for the claim made by Lord Denning MR, as it was made in the context of a suit which the solicitor in question was, in effect, wrongfully maintaining. It is a well recognised principle that a maintainer commits a tort against the 
other party to litigation if the action is unsuccessful. The duty not to maintain is one owed as an ordinary citizen, not merely as a solicitor.

There is a serious difficulty with any suggested duty owed by an advocate to the opposing litigant and its existence has been effectively rejected by the courts. It is fundamentally inconsistent with the adversarial process upon which the judicial system is based. The remarks of Lord Denning MR in Kelly were heavily criticised on this basis in Orchard $v$ South Eastern Electricity Board ${ }^{101}$ where the duty was formulated firmly as owed to the court.

In New Zealand the courts have been careful to make the distinction between the application of their inherent jurisdiction to discipline those who appear before them for breaches of the duty to the court, and claims made by litigants against opposing advocates. The fact that the authorities dealing with the inherent jurisdiction of the court do not give rise to a cause of action against advocates was clearly stated by the Court of Appeal in Gordon $v$ Treadwell Stacey Smith. ${ }^{102}$ The Court there relied on the earlier authority of New Zealand Social Credit Political League v O'Brien ${ }^{103}$ where Cooke J struck out an action against a solicitor for bringing an ill conceived action. It was there stated that unless the legal representative acted with malice, as well as without cause, no action could lie.

\section{JUSTIFYING THE SUMMARY PROCEDURE}

If an application for costs against an advocate is successful it is possible that the court will make an award against the advocate that may impose considerable financial hardship. In such circumstances an advocate may understandably wish to be fully heard on the matter to the extent of discovering documents, calling evidence, and presenting arguments in the manner of a normal trial. Such an opportunity will, however, not be given. When an application for costs against an advocate is made, although the advocate will be given an opportunity to be heard in the matter, the conduct of the hearing into costs itself will be summary. It is not regarded as a matter where interlocutories such as discovery or interrogatories would generally be appropriate. ${ }^{104}$ Provided the procedure is

\footnotetext{
101 Above n 56, 106-107.

102 [1996] 3 NZLR 281, 293 (CA).

103 Above n 19, 88 .

104 A similar summary jurisdiction over the conduct of legal practitioners is to be found in the power of the court to enforce practitioners' undertakings. See Geoffrey Silver and Drake v Baines [1971] 1 QB 396, 402 per Lord Denning MR (CA), National Westminster Finance NZ Ltd v Bryant [1989] 1 NZLR $513(\mathrm{HC})$.
} 
fair, the advocate is clearly informed of the nature of the misconduct alleged, and an opportunity to answer is given, justice will be served. ${ }^{105}$

A full and independent hearing of an application against an advocate is inappropriate for a number of reasons. It would be counter to the very spirit of the rule if, though designed to avoid multiplying litigation, it had the reverse effect. Indeed if the likely length and expense of such a costs hearing is disproportionate to the likely award, this will be a reason for refusing to entertain such an application. ${ }^{106}$ Moreover it needs to be remembered that the proceeding is a disciplinary charge against the advocate by the court as well as a claim for compensation by the successful litigant (although both purposes are served). Thus an independent action in which the litigant is a formal party akin to one for maintenance or champerty is inappropriate. The foundation of the proceeding is the court's exercise of its inherent supervisory jurisdiction over its officers, not the vindication of legal rights of a successful litigant who has been put to unnecessary expense.

Such orders are an exercise of the court's inherent supervisory jurisdiction. ${ }^{107}$ Because of this a full hearing would be inappropriate. This is demonstrated by the fact that an order that an advocate pay the costs of a litigant may be made at the court's own instance. There has been a suggestion that the court should not be too ready to initiate such an application. ${ }^{108}$ The reasoning behind such a reluctance is that the court should be careful about creating further litigation, and that if the application is ultimately declined the costs of the application will have to be borne by a party or parties that did not make the application. Whatever the origin of the application, the advocate whose conduct is under examination will be given fair warning of the possibility of the order, and an opportunity to defend themselves within the constraints of the summary procedure. ${ }^{109}$ In the absence of a fair hearing any such order will be considered per incuriam. ${ }^{110}$

The courts must also be aware that the advocate may labour under significant difficulties in defending their conduct before the court. Thus in Tolstoy-Miloslavsky $v$ Aldington $^{111}$ the court was careful when making an order against the legal advisers of the

105 Ridehalgh $v$ Horsefield above n 6, 238.

106 In Re Freudiana Holdings Ltd [1995] TLR 635 (CA).

107 The exercise of the court's inherent jurisdiction will always be summary in nature and not a separate proceeding. See J Jacob "The Inherent Jurisdiction of the Court" above n 19.

108 Ridehalgh $v$ Horsefield above n 6, 238.

109 Utah Construction and Mining Co v Watson above n 22, Abraham v Jutsun above n 71.

110 Stephens v Stephens [1991] 1 NZLR 633 (HC).

111 Above n 58, 746. 
plaintiff to point out that they had taken into account the fact that they could not disclose privileged documents or confidential information in mounting their own defence. The court must always be aware that the advocate may be unable to "tell the whole story" and in cases of doubt they are entitled to the benefit of that doubt. ${ }^{112}$

Injustice to an advocate resulting from the summary nature of the proceeding is unlikely. The threshold of hopelessness is so high that (as the cases show) there will in fact be few cases which are found hopeless in the manner described above, and in cases of doubt, or lack of evidence, the court will err in the advocate's favour. The procedure is necessary to achieve a balance between giving the advocate a fair opportunity to be heard, and ensuring that the further proceedings to which the successful litigant is subjected are kept to a minimum.

If an application that an advocate pay the costs of a litigant is to be made, it should only be made once the substantive proceedings have been disposed of. This is to avoid the use of such applications, or threats of such applications, being used as a tactic prior to trial to stifle argument, intimidate counsel, or create a conflict between client and adviser which disqualifies the adviser. ${ }^{113}$

\section{CONCLUSION}

There are numerous reasons why a litigant may want to bring a claim or mount a defence that has no prospect of success. There are similarly a number of reasons why an advocate may wish to, or be under pressure to, assist in such an endeavour. If we accept that an advocate is more than a mere agent for the client, and has an independent role to play in the administration of justice, then assisting in a case which can be shown to be hopeless must amount to misconduct. It is this premise upon which the courts have exercised their jurisdiction to award costs against advocates who bring doomed claims or defences before the court.

The courts have sought to achieve a balance between protecting those who appear before it, and ensuring that innocent victims of wrongdoing by an advocate are compensated. The rule that an advocate may not assist in bringing a hopeless case, or mounting a hopeless defence is, in fact, not as onerous as some might claim. The courts have only stepped in where a claim or defence was hopeless, and this would be apparent to any competent advocate who took the time to inquire. In cases of doubt the courts have rightly leaned in favour of the advocate. The court's jurisdiction to award costs against an advocate who assists in bringing a hopeless case is not a panacea for the

112 See also Ridehalgh $v$ Horsefield above n 6, 236.

113 Orchard v South Eastern Electricity Board above n 56, 577 per Sir John Donaldson MR, 580 per Dillon LJ; also Ridehalgh $v$ Horsefield above n 6, 237. 
proliferation of needless and doubtful litigation. However, it does set a threshold of what the court will tolerate of which all advocates would do well to be aware. 